\title{
EHMTI-0140. The potential role of levetiracetam in migraine treatment: an animal study
}

\author{
YF Wang ${ }^{1 *}$, JC Yen², LS Kao², JL Fuh', SJ Wang ${ }^{1}$ \\ From 4th European Headache and Migraine Trust International Congress: EHMTIC 2014 \\ Copenhagen, Denmark. 18-21 September 2014
}

\section{Introduction}

Cortical spreading depression (CSD) is one of the most widely used animal models of migraine. Whether levetiracetam (LEV), like other antiepileptic drugs, has a role in the treatment of migraine remains uncertain.

\section{Aim}

To investigate the potential of LEV in the treatment of migraine using a rat model of CSD.

\section{Method}

Male Sprague-Dawley rats were used. The effects of acute (3 day) and chronic (28 days) treatment with vehicle, LEV $200 \mathrm{mg} / \mathrm{kg} / \mathrm{d}$, and LEV $400 \mathrm{mg} / \mathrm{kg} / \mathrm{d}$ on CSD susceptibility were examined. Drugs were given as daily intraperitoneal injections. After completion of drug treatment, CSD was elicited by placing a cotton ball soaked with $1 \mathrm{M} \mathrm{KCl}$ onto the occipital cortex, and was recorded for 2 hours by placing a glass microelectrode into the frontal cortex.

\section{Results}

In the acute treatment experiment, rats receiving LEV $400 \mathrm{mg} / \mathrm{kg} / \mathrm{d}(8.4 \pm 1.0)$ had fewer CSDs per hour than those receiving vehicle $(12.9 \pm 1.7, \mathrm{p}<0.001)$ and LEV $200 \mathrm{mg} / \mathrm{kg} / \mathrm{d}(12.5 \pm 1.2, \mathrm{p}<0.001)$. In the chronic treatment experiment, rats receiving LEV $400 \mathrm{mg} / \mathrm{kg} / \mathrm{d}(11.4 \pm$ 0.6) had fewer hourly CSD events than those receiving vehicle $(14.3 \pm 0.3, \mathrm{P}<0.001)$ and LEV $200 \mathrm{mg} / \mathrm{kg} / \mathrm{d}$ $(13.6 \pm 0.4, \mathrm{p}<0.001)$, and rats treated LEV $200 \mathrm{mg} / \mathrm{kg} / \mathrm{d}$ had less CSDs than those in the vehicle group $(\mathrm{p}=$ 0.049).

${ }^{1}$ Department of Neurology, Taipei Veterans General Hospital, Taipei, Taiwan Full list of author information is available at the end of the article

\section{Conclusion}

LEV had a modest effect on reducing CSD susceptibility at a dose of $400 \mathrm{mg} / \mathrm{kg} / \mathrm{d}$, and the effects on CSD susceptibility were comparable when administered acutely or chronically.

Conflict of interest.

\section{Authors' details \\ ${ }^{1}$ Department of Neurology, Taipei Veterans General Hospital, Taipei, Taiwan. \\ ${ }^{2}$ School of Medicine, National Yang-Ming University, Taipei, Taiwan.}

Published: 18 September 2014

doi:10.1186/1129-2377-15-S1-F30

Cite this article as: Wang et al: EHMTI-0140. The potential role of

levetiracetam in migraine treatment: an animal study. The Journal of

Headache and Pain 2014 15(Suppl 1):F30.

\section{SpringerOpen ${ }^{\odot}$}

C 2014 Wang et al; licensee Springer. This is an Open Access article distributed under the terms of the Creative Commons Attribution License (http://creativecommons.org/licenses/by/2.0), which permits unrestricted use, distribution, and reproduction in any medium, provided the original work is properly cited.
Submit your manuscript to a SpringerOpen ${ }^{\circ}$ journal and benefit from:

- Convenient online submission

- Rigorous peer review

- Immediate publication on acceptance

- Open access: articles freely available online

- High visibility within the field

- Retaining the copyright to your article

Submit your next manuscript at $>$ springeropen.com 